\title{
Biomarkers for the Diagnosis, Prognosis, and Evaluation of Treatment Efficacy for Traumatic Brain Injury
}

\author{
Pramod K. Dash, ${ }^{*}$ Jing Zhao, ${ }^{*}$ Georgene Hergenroeder, ${ }^{\dagger+}$ and Anthony N. Moore* \\ *Department of Neurobiology and Anatomy, ${ }^{\dagger}$ Department of Neurosurgery, and the ${ }^{\ddagger}$ Vivian L. Smith Center for Neurologic \\ Research, The University of Texas Medical School, Houston, Texas 77225
}

\begin{abstract}
Summary: Traumatic brain injury (TBI) remains a serious health concern, and TBI is one of the leading causes of death and disability, especially among young adults. Although preventive education, increased usage of safety devices, and TBI management have dramatically increased the potential for surviving a brain injury, there is still a need to develop reliable methods to diagnose TBI, the secondary pathologies associated with TBI, and predicting the outcomes of TBI. Biomarkers (changes of amount or activity in a biomolecule that reflect injury or disease) have shown promise in the diagnosis of several conditions, including cancer,
\end{abstract}

heart failure, infection, and genetic disorders. A variety of proteins, small molecules, and lipid products have been proposed as potential biomarkers of brain damage from TBI. Although some of these changes have been reported to correlate with mortality and outcome, further research is required to identify prognostic biomarkers. This need is punctuated in mild injuries that cannot be readily detected using current techniques, as well as in defining patient risk for developing TBI-associated secondary injuries. Key Words: Blast injury, diffused axonal injury, intracranial pressure, loss of consciousness, post-concussive symptoms, PTSD.

\section{TRAUMATIC BRAIN INJURY: A GLOBAL HEALTH PROBLEM}

The human brain is highly vulnerable to injuries that can cause profound cognitive and neurobehavioral dysfunction, compromising quality of life. TBI can result from shearing forces caused by a sudden change in acceleration to deceleration (e.g., vehicular accidents), from impacts (e.g., falls, blunt force trauma), as a result of rapid changes in pressure (e.g., blast exposure), or by penetration by high-velocity projectiles (e.g., bullets, blast/shrapnel). Considered a "silent epidemic" in the United States, TBI has its greatest impact on young men and women. These patients (mean, 29.5 years) pose a tremendous burden to families and society in terms of years of lost productivity, increased demands on the healthcare system, and reduction in healthy life spans. Approximately 5.3 million in the United States alone are living with disabilities resulting from TBI.

One of the primary causes of death after a trauma is brain injury. In less developed countries, traffic accidents are the most significant cause of brain injury, with most accidentrelated fatalities being linked to brain damage. According to a World Health Organization, World Bank report titled,

Address correspondence and reprint requests to: Pramod Dash, Department of Neurobiology and Anatomy, The University of Texas Medical School, P.O. Box 20708, Houston, TX 77225. E-mail: p.dash@uth.tmc.edu.
"The Global Burden of Disease," traffic injuries are expected to become the third highest disease burden by the year 2020. For example, every motor vehicle injury that results in death in the United States, 13 people sustain injuries severe enough to require hospitalization, according to the World Health Organization report titled, "The Injury Pyramid." The majority of injuries from these types of brain trauma are caused by sudden changes in inertia (rapid acceleration and deceleration) leading to distortion of the brain tissue within the skull. A primary feature of this type of injury is axonal damage, often referred to as diffuse axonal injury.

In this century, brain injuries resulting from blasts have emerged as the major cause for TBIs among military personnel. The number of TBI casualties, sustained by Coalition Forces engaged in the wars in Afghanistan, Operation Enduring Freedom, and Operation Iraqi Freedom during the past 5 years, indicates that TBI will continue to be a major threat to military personnel in the 21 st century. ${ }^{1,2}$ According to the Joint Theater Trauma Registry, compiled by the U.S. Army Institute of Surgical Research, 22\% of wounded soldiers from Iraq and Afghanistan have injuries of the head, face, or neck, which has substantially increased in comparison with the casualties suffered in the Vietnam War. ${ }^{3}$ At least some of this increase in TBI is due to increased survivability, resulting from improvements in body armor and helmet design, and rapid medical intervention. However, knowl- 
edge of the pathophysiology of TBI resulting from blasts is in an infant stage. Recent studies are beginning to show there may be a number of differences between acceleration and deceleration from blast-induced TBI in terms of neurochemical changes, cell death, and outcome.

Although TBI resulting from vehicular accidents is on the decline, as a result of enforced seat-belt laws and other safety laws, penetrating brain injury from gunshots, knives, and blast/shrapnel is on the rise. This type of injury often causes cavitations resulting from the transfer of kinetic energy from the high-power projectile into the soft brain tissue. Depending on the path of the projectile, penetrating injury can cause profound deficits in specific sensory, motor, or cognitive domains, and is often associated with posttraumatic epilepsy. In the case of shrapnel injuries, persons may have mixed pathologies caused not only by the penetration of the projectile, but as a result of the blast overpressure. These types of mixed injuries are most commonly observed in soldiers exposed to improvised explosive devices.

The incidence of TBI can be reduced by preventive education programs (such as drunk driving prevention), and the severity of the primary injury can be lessened through the use of improved protective equipment (such as the use of helmets for athletes and body armor for military personnel). However, an effective clinical therapy to treat human brain injury is not yet available.

\section{PRIMARY AND SECONDARY INJURIES ARE KEY FEATURES OF TBI}

The pathology of TBI reflects the initial insult, resulting from mechanical damage to neural and vascular structures (the primary injury), and the evolution of a cascade of secondary events that impair function, damage structures, and promote further cell death (the secondary injury). ${ }^{4}$ The primary injury results from the deformation of grey and white matter leading to the distortion and/or disruption of cell membranes and release of intracellular contents. In human TBI, there is a heterogeneity (i.e., focal, multifocal, or diffuse) that is associated with the primary insult. The evolution of secondary damage represents a cascade of biochemical and molecular events that collectively mediate cell damage. The extent or severity of secondary damage is at least partly dependent on the proximity and/or connectivity of the affected tissue to the areas of primary damage, and is also dependent on the relative vulnerability of the different cell types from which it is composed.

Some of the earliest findings in the injured brain include damage to axons, excessive neuronal activity (reflected in part from unregulated glutamate release), widespread changes in neurotransmitter levels, altered cerebral blood flow, hemorrhage, and disruption of the blood-brain barrier. Coincident with these events are physiologic disturbances including hypotension, hypoxemia, elevated intracranial pressure, decreased cerebral perfusion pressure, edema, ischemia, and silent seizures (in many cases).

\section{TBI BIOMARKERS}

A biomarker is an indicator of a specific biological or disease state that can be measured using samples taken from either the affected tissue or peripheral body fluids. These markers can be altered enzymatic activity, changes in protein expression, or post-translational modification, altered gene expression, protein, or lipid metabolites, or a combination of these changes. As a consequence, a variety of strategies have been used for biomarker discovery including transcriptional profiling, proteomic and metabolomic approaches.

The two most commonly used approaches for biomarker discovery are "top-down" and "bottom-up" methodologies. In a top-down approach, potential biomarkers are evaluated based on their known involvement in the disease state. For instance, the cell death that occurs after TBI in the core of the primary injury is largely necrotic in nature. As necrosis is associated with calpain activation, specific protein degradation profiles will be generated (both in terms of the resultant peptide fragments and the time course of their appearance), giving rise to putative biomarkers of necrosis. ${ }^{5}$ These markers would be distinct from those biomarkers generated as a result of apoptotic cell death, because apoptosis is associated with activation of caspases and is typically more delayed in progression. ${ }^{6,7}$ Although the "top-down" approach has been used to discover biomarkers associated with TBI, many of these markers were first identified in the injured brain, and then their presence in a more accessible sample source (e.g., blood, urine, and so on) was examined. If the biomarker is absent (or present in very low amounts) in the peripheral bodily fluids, its usefulness for diagnostic purposes may be lessened. A "bottom-up" approach examines changes in the composition of a tissue or bodily fluid, and then attempts to establish links between these changes and pathology. Although a "bottom-up" approach using a sample source, such as serum for example, may overcome the potential problem of biomarker detectability; this approach often identifies general markers that are not solely indicative of the condition of interest. As an example of using serum samples from severely injured TBI patients and healthy volunteer controls, $\mathrm{C}$-reactive protein and serum amyloid A have been reported to be capable of distinguishing between these two groups. ${ }^{8}$ However, both of these proteins are general indicators of injury/infection, making them less likely to distinguish brain injury patients from persons with other bodily injuries. On the other hand, if 
brain injury alone is suspected, or if these markers were used in combination with other biomarkers, a rise in the levels of these proteins in serum may further support a brain injury diagnosis.

\section{Protein biomarkers of TBI}

To date, the majority of TBI biomarker research has focused on protein profiling. However, as the human genome is estimated to contain $\sim 23,000$ genes, and as many as $50 \%$ of the translated proteins are considered to be low in abundance, surveying the entire proteome is a daunting endeavor. For instance, the Human Proteome Organization collaborative initiative has identified only 889 abundant serum proteins (using two-dimensional gel mass spectrometry) with a confidence level of at least $95 \% .^{9}$ This suggests that $<10 \%$ of the "core" serum proteins (estimated to contain at least 10,000 proteins) are effectively being sampled. To enhance the probability of detecting low-abundance protein biomarkers, a number of methods have been used including fractionation, immunodepletion of abundant proteins, the use of subproteome (e.g., inflammatory proteome, glycoproteome, phosphoproteome) arrays, and isolation techniques, such as combinatorial ligand libraries. The advantages and disadvantages of these approaches have been reviewed elsewhere. ${ }^{10-12}$

\section{S100B}

The most extensively studied TBI biomarker is S100B. Changes in the expression of this marker have been shown to correlate with injury magnitude, survivability, and neurologic outcome. ${ }^{13} \mathrm{~S} 100 \mathrm{~B}$ is a low molecular weight $(10.5 \mathrm{kDa})$ calcium-binding protein that is primarily expressed and secreted by astrocytes, constituting 1 to $1.5 \mu \mathrm{g} / \mathrm{mg}$ of all soluble protein. S100B can be found in very low levels in human CSF and serum, and normal levels of this protein have been strongly correlated with the absence of intracranial injury. ${ }^{14}$ After brain injury, S100B is released into the CSF and serum. The serum half-life of S100B is less than $60 \mathrm{~min}$ and can be readily detected soon after injury. Increased levels of this protein have been proposed as biomarkers of poor outcome. For example, Vos et al. ${ }^{15}$ demonstrated that in patients with severe TBI, serum S100B concentrations $>1.13 \mathrm{ng} / \mathrm{mL}$ were associated with increased mortality (100\% sensitivity; $41 \%$ specificity) and morbidity ( $88 \%$ sensitivity; $43 \%$ specificity). The low basal levels of S100B in human serum allow increases in the concentrations of this protein to be very sensitive indicators of brain injury. However, several recent observations concerning S100B have tempered the original enthusiasm regarding the usefulness of this protein as a biomarker. First, because S100B does not cross the intact blood brain barrier, there is a poor correlation between its levels in the CSF and those detected in the serum. This has raised concerns as to whether the serum levels of this protein actually correlate with the degree of brain dam- age or are more reflective of blood brain barrier (BBB) disruption. Secondly, S100B has been reported to be released into the serum after experimental ischemic injury to the liver, kidney, and gut; ${ }^{16}$ its levels have been found to have increased after extracranial trauma ${ }^{14}$ and burns, ${ }^{17}$ and it has been suggested to be a biomarker of melanoma. ${ }^{18}$ Finally, conflicting reports have been published regarding the usefulness of this marker in predicting outcome after pediatric TBI. ${ }^{19-21}$

\section{Glial fibrillary acidic protein}

The glial fibrillary acidic protein (GFAP) is a monomeric intermediate filament protein expressed by astrocytes. It is a brain-specific protein that is released after TBI. ${ }^{15,22-24}$ Increases in serum GFAP levels after TBI have been shown to be predictive of elevated intracranial pressure (ICP), reduced mean arterial pressure, low cerebral perfusion pressure, poor Glasgow outcome scores (GOS), and increased mortality. For example, GFAP serum concentrations $>1.5 \mathrm{ng} / \mathrm{mL}$ were found to be predictive of death ( $85 \%$ sensitivity; $52 \%$ specificity) or poor outcome (GOS at 6 months; $80 \%$ sensitivity; 59\% specificity). ${ }^{15}$ Consistent with its brain-specific expression, GFAP levels were found to be normal in multitrauma patients that did not have brain injury. ${ }^{24}$

\section{Neuron-specific enolase}

The neuron-specific enolase (NSE) is one of the five isozymes of the glycolytic enzyme, enolase. NSE was initially found to be expressed in neurons, but has subsequently been identified in neuroendocrine cells, oligodendrocytes, thrombocytes, and erythrocytes. NSE has a serum half-life of approximately 24 hours and can be detected within 6 hours of injury. The serum level for NSE (normally $<12.5 \mathrm{ng} / \mathrm{mL}$ ) has been reported to increase after TBI, the levels of which have been correlated with the severity of the injury. ${ }^{25-27}$ At serum levels $>21.7 \mathrm{ng} / \mathrm{mL}$, NSE has been demonstrated to be a sensitive indicator of mortality ( $85 \%$ sensitivity) and poor outcome ( $80 \%$ sensitivity). However, inadequate sensitivity and specificity have limited the use of NSE regarding the neuropsychological outcome (55\% sensitivity; $77.8 \%$ specificity) and predicting the presence of intracranial lesions (77\% sensitivity; $52 \%$ specificity). ${ }^{15,28,29}$ Used in isolation, elevated serum NSE levels do not necessarily indicate the presence of brain trauma, as this protein has also been suggested to be a marker for small cell lung cancer, neuroendocrine bladder tumors, ischemic stroke, and neuroblastomas.

\section{Myelin basic protein}

The myelin basic protein (MBP) is a major protein component of myelin, and is released into the CSF and blood after white matter injury. Normal serum levels of MBP are very low, typically $<0.3 \mathrm{ng} / \mathrm{mL}$. In a study of pediatric brain injury, high serum MBP levels were found to correlate with worse outcome. ${ }^{30}$ Interestingly, 
this same study demonstrated that MPB levels were not increased in children with hypoxic-ischemic encephalopathy. This is consistent with previous observations that ischemic injury does not cause disruptions of white matter.

\section{Fatty acid binding proteins}

The fatty acid binding proteins (FABPs) are expressed in multiple tissues, with the exception of brain typeFABP (B-FABP), which is expressed exclusively in the brain. ${ }^{31}$ In a study to evaluate the clinical usefulness of B-FABP as a biomarker of brain injury, Pelsers et al. ${ }^{32}$ reported that B-FABP could be detected in the serum of $68 \%$ of the mild TBI patients examined. No B-FABP could be detected in the serum of healthy volunteer controls. Although FABP is not highly sensitive, it proved to be more accurate in identifying mild TBI patients as compared with S100B (increase of $45 \%$ of mild TBI patients) or NSE (increase of $61 \%$ of mild TBI patients).

\section{Proteolytic breakdown products}

One of the key pathological features of TBI is the unregulated breakdown of cellular proteins by protease families such as calpain and caspase. Recently, BDPs of the structural protein $\alpha$-II spectrin and the dendritically enriched microtubule-binding protein tau have been shown to correlate with injury severity in rodent models of TBI, and in human TBI patients. ${ }^{33,34}$ For example, the levels of calpaincleaved $\alpha$-II spectrin BDPs, but not the level of S100B, in the ipsilateral cortex and CSF of rats subjected to cortical impact injury were found to correlate with lesion size. ${ }^{35} \mathrm{In}$ humans, the levels of spectrin BDPs were initially found to be upregulated in the CSF of patients with severe TBI, but decreased at between 6 to 96 hours in those with a better outcome. ${ }^{36}$ Measurement of cleaved tau (C-tau) levels in the serum of brain injured rats also revealed a significant increase in these BDPs by 6-h post-injury. ${ }^{33}$ Consistent with this, the initial post-injury CSF levels of C-tau were found to be elevated in patients with severe TBI, correlated with clinical outcome (92\% sensitivity; $94 \%$ specificity), and predicted elevated ICP (78\% sensitivity; $79 \%$ specificity). ${ }^{37}$

\section{Phosphorylated neurofilament}

A recent addition to the growing number of neuronspecific protein markers of injury is phosphorylated neurofilament $\mathrm{H}$. Using a rodent model of TBI, Anderson et al. ${ }^{38}$ demonstrated that phosphorylated neurofilament $\mathrm{H}$ could be detected early (within 6-h post-injury) in the blood of animals with brain injuries. Peak levels (detected 24-48-h post-injury) were found to correlate with the volume of the injured cortex. The sensitivity of this marker in detecting human brain injury has not yet been investigated.

\section{Ubiquitin C-terminal hydrolase}

The ubiquitin C-terminal hydrolase is enriched in neurons; therefore it has been proposed to be a putative biomarker for TBI. To test this possibility, Papa et al. ${ }^{39}$ carried out a prospective study to determine the CSF levels of ubiquitin C-terminal hydrolase in patients who had severe brain injury and in uninjured controls. They found that ubiquitin C-terminal hydrolase levels were significantly increased in the CSF of brain-injured patients, and that the magnitude of this increase correlated with mortality, post-injury complications, and outcome tested 6 months post-discharge.

\section{INFLAMMATORY MARKERS}

Increased serum and/or CSF concentrations of proand anti-inflammatory cytokines, chemokines, and acute phase reactant proteins have been observed after TBI. The importance of inflammation on the progression of TBI-associated pathologies has been the focus of numerous studies. ${ }^{40-43}$ More recently, the expression of these factors has been appreciated as potential markers of injury, and studies have been carried out to test if their levels correlate with outcome or can serve as surrogate markers of treatment efficacy. Acute phase proteins (e.g., C-reactive protein, amyloid A, pro-inflammatory cytokines [e.g., IL-1, TNF- $\alpha$, IL-6], and anti-inflammatory cytokines [IL-10, transforming growth factor beta, or TGF- $\beta$ ] and chemokines [e.g., ICAM-1, macrophage inflammatory protein (MIP)-1, MIP-2]) have been reported to change in response to TBI. The CSF and/or serum levels of a number of these markers have been correlated with injury, and in some cases with outcome. For example, it has been reported that the acute phase reactant proteins $\mathrm{C}$-reactive protein and serum amyloid A are rapidly increased in the serum of brain trauma patients. ${ }^{8}$ Using a multiplex approach to simultaneously evaluate a panel of chemokines and cytokines, Buttram et al. ${ }^{44}$ reported that severe TBI in children was associated with significant increases in the CSF levels of interleukin (IL)-1 $\beta$, IL-6, IL-12p70, IL-10, IL-8, and MIP-1 $\alpha$. Because the injury to other organs can increase the serum level of these markers, these markers by themselves may not provide high specificity. However, the temporal changes in the serum levels of these cytokines may be different after TBI and injury to other organs. Furthermore, in certain situations in which selective brain injury is suspected (e.g., inflicted TBI), these markers can be helpful in diagnosing TBI. ${ }^{45}$

\section{Interleukin-1}

Since the earliest study suggesting that IL-1 may contribute to the development of astroglial scars after brain injury, ${ }^{46}$ IL-1 has been extensively studied after TBI. For example, Singhal et al. ${ }^{47}$ evaluated the levels of IL-1 and 
IL-6 in the CSF of severe brain injury patients and found peak IL-1 levels correlated with 3-month outcomes. Both in adult and pediatric TBI patients, high CSF IL-1 levels have been shown to indicate a poor GOS. ${ }^{48}$

\section{Tumor necrosis factor}

Tumor necrosis factor (TNF)- $\alpha$ as a pro-inflammatory factor has been shown to play an important role in the immune response. A major immune function of TNF- $\alpha$ is stimulating neutrophil and monocyte recruitment to the site of injury to phagocyte debris. In the CNS, TNF- $\alpha$ is mainly secreted by microglia but can also be released by other cells including astrocytes, neurons, and endothelial cells. ${ }^{49-52}$ Increased TNF- $\alpha$ concentrations in serum and CSF have been reported in human TBI cases. ${ }^{53-55}$ In a prospective study to examine the correlation between serum TNF- $\alpha$ levels and mortality, Crespo et al., ${ }^{53}$ found that although initial TNF- $\alpha$ levels were significantly increased in the serum of severely injured patients, this increase did not correlate with mortality.

\section{Interleukin-6}

A number of studies performed in animals and humans with TBI have reported changes in CSF and serum levels of the cytokine IL- 6 . The CSF levels of IL- 6 reach a maximum between days 3 and 6 in TBI subjects, ${ }^{56}$ with the severity of injury being related to the degree of intracranial IL-6 gradient (venous to arterial ratio) at the time of admission. ${ }^{57}$ An in vivo microdialysis study has shown that increased parenchymal IL-6 levels correlate with survival and GOS suggesting that IL-6 is an endogenous neuroprotective cytokine. ${ }^{58}$ Furthermore, increased CSF levels of IL-6 have been reported to correlate with improved outcome in pediatric TBI. ${ }^{59}$ Interestingly, induced hypothermia has no effect on IL-6 levels in children, a finding that is in contrast to that observed in adult TBI patients in which IL-6 levels were found to decrease after therapeutic hypothermia. ${ }^{60}$

\section{Anti-inflammatory cytokines}

The anti-inflammatory cytokines (e.g., IL-10, TGF- $\beta$ ) counteract the detrimental effects of pro-inflammatory molecules such as IL- 1 , TNF- $\alpha$, and IFN- $\gamma,{ }^{61}$ and have been reported to also be increased as a result of TBI. For example, the CSF levels of IL-10 increase within the first $24 \mathrm{~h}$ of TBI. This rise in CSF IL-10 is associated with a corresponding decrease in TNF- $\alpha$ levels, consistent with its anti-inflammatory function. ${ }^{62}$ Increase in IL-10 levels has been shown to correlate with mortality in pediatric TBI. ${ }^{63}$ TGF- $\beta$ is a member of a large super family of growth factors that are important for a number of biological functions including cell growth and differentiation, angiogenesis, immune function, extracellular matrix production, cell chemotaxis, and apoptosis. There are approximately 25 members in this family, which includes activins, inhibins, bone morphogenetic proteins, growth and differentiation factors, and glial-derived neurotrophic factor. ${ }^{64}$ After TBI, the CSF levels of TGF- $\beta$ are rapidly increased (peaking by $24-\mathrm{h}$ post-injury), and they remain at this level for $>3$ weeks. ${ }^{65}$

\section{Chemokines}

The chemokines play a vital role in TBI-associated brain inflammation. They recruit peripheral immune cells into the injured brain, where these cells release a number of cytokines and also provide scavenging functions. For example, increased expression of ICAM-1 is critical for neutrophils to traverse across the BBB. It appears that the degree of BBB compromise correlates with serum ICAM levels after TBI. ${ }^{66}$ Monocyte chemo-attractant protein-1 is important for the recruitment of monocytes into the brain. Using rodent TBI models, it has been reported that expression of monocyte chemo-attractant protein-1 is enhanced in the brain by $4-\mathrm{h}$ post-injury. ${ }^{67}$ However, its diagnostic value for the detection of human TBI has not been examined.

\section{SMALL MOLECULE BIOMARKERS}

Metabolites of neurotransmitters, second messengers, ions, and glycolytic intermediates have a rich history as potential biomarkers for primary and secondary injury. ${ }^{68-71}$ The first such marker to be tested was cAMP when Rudman and colleagues ${ }^{72}$ measured the levels of cAMP in the CSF as a putative biomarker for the depth of coma. The concentration of CAMP in CSF was found to correlate with the grade of coma with a coefficient of $-0.8 .^{73}$ Since that time, several "top-down" studies have been carried out to evaluate the levels of small molecules for their ability to diagnose TBI, or to correlate with its severity. For example, Clifton et al. ${ }^{74}$ demonstrated that serum norepinephrine levels, although normal in TBI patients with a Glasgow coma score (GCS) of 14, dramatically increased in comatose patients. Interestingly, in polytrauma patients, norepinephrine was increased regardless of GCS. The concentration of metabolites of dopamine (homovanillic acid) and serotonin (5-hydroxyindolacetic acid) have also been reported to increase in the CSF of TBI patients, ${ }^{75,76}$ with elevations in 5hydroxyindolacetic acid being reliable indicators of trauma.

In addition to altered neurotransmitter metabolism, a number of studies have shown that TBI alters the levels of glucose, lactate, pyruvate, glycerol, and glutamate, both in the CSF and in microdialysates obtained from the injured brain. For example, lactate accumulation in the CSF after craniocerebral injury has been shown to correlate with injury severity. ${ }^{77}$ Furthermore, clinical hypothermia reduces lactate levels, ${ }^{78}$ suggesting that this small molecule biomarker may be able to serve as a surrogate marker of treatment effectiveness. $\mathrm{N}$-acetylas- 
partate (NAA), a derivative of aspartate, is present in high levels in the brain (NAA comprises up to $0.1 \%$ of the wet weight of the brain). ${ }^{79}$ In the brain, NAA is abundantly present in neurons and their processes, and its decrease is considered a marker for injury. NAA can be detected as a single intense peak at $2.02 \mathrm{ppm}$ by proton MR spectroscopy. For example, Yeo et al. ${ }^{80}$ have measured the ratios of NAA/creatine and choline/creatine in the anterior and posterior halves of the supraventricular region of the brain in pediatric TBI patients. Their findings indicate that that each ratio predicts aspects of neuropsychological deficits indicating the usefulness of measuring region/structure-specific biomarker measurements.

\section{LIPID METABOLITES AS BIOMARKERS}

The brain has high levels of fatty acids, yet relatively low levels of antioxidant enzymes, making it susceptible to oxidative damage. Lipid peroxidation, which leads to changes in the biophysical properties of cell membranes and the functions of membrane-bound proteins, is one of the principal consequences of oxidative damage after TBI. As such, lipid peroxidation products have drawn attention as putative biomarkers of injury.

\section{F2-isoprostane}

The F2-isoprostanes represent a group of prostaglandin-like compounds produced from arachidonic acid as a result of peroxidation. Elevated F2-isoprostane levels have been reported in various human diseases, including cardiovascular diseases such as ischemia and atherosclerosis, lung diseases such as asthma and chronic obstructive pulmonary disease, and neurological diseases such as Alzheimer's disease and multiple sclerosis. ${ }^{81}$ Multiple studies have shown that brain injuries increase the levels of F2-isoprostane both in the CSF and the serum of TBI patients. ${ }^{82-84}$ For example, Varma et al. ${ }^{85}$ demonstrated that in children who had severe TBI, the level of F2isoprostane was elevated by 6 -fold compared with that observed in uninjured controls. This marker was found to correlate well with the appearance of NSE, further supporting its use as an indicator of brain damage. In adults, a gender bias was found in that males had approximately twice the levels of CSF F2-isoprostane than females, and only males had decreased levels of this lipid metabolite in response to hypothermia. ${ }^{86}$ This disparity in lipid peroxidation has been proposed to be a potential reason for the greater neuroprotection seen in females than in males. Although F2-isoprostane levels have been called the "gold standard" of lipid peroxidation, determination of its levels requires specialized equipment, thereby limiting its clinical usefulness.

\section{4-Hydroxynonenal}

The 4-hydroxynonenal (4-HNE), an endogenous end product of lipid peroxidation, is another well accepted lipid peroxidation marker. Although being an amphiphilic compound, 4-HNE is more concentrated in membranes where it reacts with membrane-bound proteins and phospholipids, compromising their functions. ${ }^{87}$ Elevated 4-HNE level has been observed in both cortical and hippocampal tissues early after TBI in animal models, ${ }^{88,89}$ and reduced 4 -HNE level has been found in parallel with neuroprotective effects in animals treated with antioxidants. ${ }^{90}$ Although in TBI-related studies, 4-HNE levels were evaluated in brain tissue, studies examining this compound in CSF and plasma have been carried out for other neurologic disorders such as Alzheimer's disease, amyotrophic lateral sclerosis, and stroke. ${ }^{91-93}$

\section{BIOMARKERS FOR MILD TBI}

Although approximately $80 \%$ of all TBI cases are believed to be mild, proper diagnosis of these patients remains a challenge. Current diagnosis of mild traumatic brain injuries (MTBIs) resulting from a blast is largely based on the Military Acute Concussion Evaluation (MACE) (see www.DVBICE.org). In the presence of the loss of consciousness or post-traumatic amnesia, a MTBI can be readily diagnosed. However, it is challenging to properly diagnose these patients who have an altered consciousness, but no loss of consciousness, post-traumatic amnesia, or without a positive head computed tomographic (CT) scan. The Military Acute Concussion Evaluation can provide positive diagnosis when administered $<12$ hours after injury. It can be erroneous when administered at a later time point. Soldiers engaged in Operation Enduring Freedom and Operation Iraqi Freedom are constantly exposed to blasts of different degrees (i.e, some close and some at a distance). It is often difficult for these soldiers to recall that they have been exposed to a blast if tested days or months after the initial event. Post-concussive symptoms including headaches, sleep disturbances, nausea, impaired attention, and memory problems are hallmarks of MTBI. Approximately $20 \%$ of patients with these symptoms remain unemployed at 1-year post-injury. ${ }^{94}$ As the consequences of MTBI can be long-lasting, there is an urgent need to identify biomarkers that can be used to assist in the diagnosis of this condition.

A number of studies have examined the serum levels of S100B as a diagnostic marker of MTBI. Similar to that observed at higher injury magnitudes, the serum concentration of this marker is transiently increased after MTBI. ${ }^{14}$ For example, a clinical study evaluating serum S100B levels in patients with mild head injuries found that patients with intracranial injuries (as determined by using head CT scans) had significant elevations in S100B levels compared with patients who did not have such injuries. ${ }^{95}$ Consistent with this evaluation, a recent re- 
evaluation of six prospective clinical trials involving more than 2000 MTBI patients indicated that S100B has a sensitivity of $98.2 \%$ in identifying the presence of brain injury. ${ }^{96}$ Although the sensitivity of this biomarker can be high, it has low specificity. ${ }^{97,98}$ For example, in a prospective cohort study, Nygren et al. ${ }^{99}$ demonstrates that while S100B levels were significantly increased in the serum of MTBI patients compared with uninjured controls, these levels could not be used to differentiate between TBI and orthopedic injury groups.

In contrast to the high sensitivity but low specificity seen with S100B after MTBI, NSE has the opposite problem as a biomarker of MTBI. Ingebrigtsen and Romner ${ }^{100}$ evaluated the diagnostic potential of NSE after MTBI and found that although this marker had high specificity, it was not very sensitive. This is likely due to the relatively small increase in serum NSE levels found as a result of MTBI. ${ }^{101}$ One of the few other biomarkers that have been clinically tested in MTBI patients is tau. To test the diagnostic accuracy of C-tau in identifying MTBI patients with intracranial injuries, Kavalci et al. ${ }^{102}$ examined serum tau levels from 88 MTBI patients and correlated these changes with the presence or absence of intracranial lesions on their head CT. No significant difference in tau protein levels was detected between the two groups. In addition, no relationship has been found between initial serum C-tau levels and 3-month outcome. ${ }^{103}$

\section{BIOMARKERS FOR DIFFERENTIALLY DIAGNOSING MILD TBI VS PTSD}

Post-traumatic stress disorder (PTSD) is an anxiety disorder characterized by a cluster of symptoms summarized as avoidance, intrusive thoughts/re-experiencing, and hyperarousal. These symptoms are evident after a person is reminded of a traumatic event by a personal "trigger" and this causes extreme distress. PTSD and MTBI patients share a number of similarities in cognitive dysfunction including deficits in attention and difficulties with episodic and working memory. ${ }^{104,105}$ These similarities in symptomatology make an accurate diagnosis between MTBI and PTSD difficult. A few MRI studies have reported that patients with PTSD have smaller hippocampal volumes, which could be used for the diagnosis of PTSD. ${ }^{106,107}$ However, it has been argued that smaller hippocampal volume may reflect a pre-existing vulnerability rather than resulting from the traumatic event. ${ }^{108}$ It is believed that PTSD symptoms result from a hypoactive medial prefrontal cortex and a hyperactive amygdala, which is supported by experimental findings in animals and humans. ${ }^{109}$ However, comparative studies are needed to determine if this imaging marker is uniquely associated with PTSD, but not with MTBI or chronic stress.
A number of neurochemicals have been identified as potential biomarkers for PTSD. ${ }^{10,111}$ Many of these changes result from altered function of the hypothalamic-pituitary-adrenal (HPA) axis. For example, it has been reported that high levels of plasma norepinephrine are related to increased risk of PTSD. When faced with a stressful situation, increases in catecholamine levels elevate heart rate, blood pressure, and blood glucose. Shortly after being exposed to a trauma, individuals who develop PTSD have higher heart rates than those who do not. ${ }^{112,113}$ Measurement of neuropeptide $\mathrm{Y}$ indicates that its serum levels are higher in veterans without PTSD as compared with veterans with PTSD. These results suggest that that neuropeptide $\mathrm{Y}$ levels may represent a biomarker for resilience to PTSD (a process of adapting well when faced with trauma, serious threats, and so on) rather than a diagnostic marker. ${ }^{114}$ Finally, dehydroepiandrosterone and dehydroepiandrosterone/cortisol ratios have been linked to PTSD. However, it is unclear if this ratio is a marker for symptom severity or if it is related to symptom improvement. ${ }^{115}$ Because TBI can alter the function of the hypothalamic-pituitary-adrenal axis, it remains to be determined if the degree and/or a combination of these changes can be used to differentiate people with mild TBI from those with PTSD.

\section{BIOMARKERS FOR PENETRATING TBI}

TBI resulting from high-velocity projectiles (e.g., bullets, shrapnel) is on the rise both among civilians and the military. A recent retrospective study at the National Naval and Walter Reed Army Medical Centers has indicated $56 \%$ of severe military TBI casualties were caused by penetrating injuries resulting from either embedded fragments driven into the brain by an explosive blast event $(72 \%)$ or from bullets from assault weapons $(23 \%) .{ }^{116}$ Yao et al. ${ }^{117}$ have used a high throughput immunoblotting technique to search for biomarkers for penetrating ballistic-like brain injuries. Using a total of 998 well-characterized monoclonal antibodies, these investigators have identified 18 proteins whose tissue levels are altered in a penetrating ballistic-like brain injury model. The most interesting of these is a precursor protein of endothelial monocyte-activating polypeptide II. The levels of this protein were increased after penetrating brain injury and decreased after middle cerebral artery occlusion, a stroke model. This indicates that different types of brain injury can potentially be diagnosed with appropriate biomarkers or a biomarker signature.

\section{BIOMARKERS FOR SECONDARY PATHOLOGIES}

Secondary injury encompasses a number of pathological processes that can continue to evolve during a period of 
days, weeks, or even months after the primary insult. These secondary pathological processes include breakdown of the $\mathrm{BBB}$, neuroinflammation, altered ionic homeostasis, cerebral edema (fluid-mediated swelling), increased ICP, impaired metabolism, hypotension, ischemia, and cell death. Because these pathologies evolve in time after the primary injury, they may provide a window of opportunity for therapeutic intervention. Although a number of researchers have focused on identifying biomarkers to diagnose injury severity and survivability, only a few groups have focused on identifying prognostic biomarkers for these secondary pathologies. The discovery of biomarkers for these secondary injuries would greatly aid in the design of management strategies for individual patients.

\section{Intracranial pressure}

One of the primary considerations of clinicians caring for TBI patients is controlling elevated ICP. Sustained elevated ICP measurements $>20 \mathrm{mmHg}$ have been linked to increased morbidity and mortality in TBI patients. ${ }^{118}$ Elevated ICP can lead to further brain tissue damage via cerebral hypoperfusion, secondary ischemia, and brain tissue herniation, and may eventually result in death. ${ }^{119}$ In a prospective study comparing the levels of C-tau between severe TBI and neurologic and non-neurologic controls, Zemlan et al. ${ }^{37}$ reported that serum C-tau levels could be used to differentiate those TBI patients with an ICP $<30 \mathrm{mmHg}$ from those with an ICP $>30 \mathrm{mmHg}$. The serum levels of GFAP and S100B have also been proposed as markers capable of differentiating between TBI patients based on their ICP status. Pelinka and colleagues, ${ }^{120}$ evaluating serum GFAP and S100B levels in 92 TBI patients, found that these proteins were significantly elevated in patients with ICP $>25 \mathrm{mmHg}$. Using a "bottom-up" approach, it has been found that the serum concentration of retinol binding protein 4 , measured between $24-$ and $36-\mathrm{h}$ post injury, is predictive of subsequent increase of intracranial pressure $(86 \%$ sensitivity; $88 \%$ specificity). ${ }^{8}$ However, the transient nature and relatively small magnitude of this change likely limits its clinical usefulness. Ceruloplasmin, also called iron(II):oxygen oxidoreductase, is the major copper carrier protein in the blood and plays an important role in copper and iron metabolism. ${ }^{121}$ Consistent with its role as an acute phase reactant, it has been found that ceruloplasmin levels are significantly increased in severe TBI patients $(\mathrm{GCS}<8)$ by 3 days post-injury. However, prior to this delayed increase, ceruloplasmin levels during the first $24 \mathrm{~h}$ after injury were found to be significantly reduced in patients who subsequently developed high ICP (i.e., ICP $\geq 25 \mathrm{mmHg}$ ). ${ }^{122}$ This decrease was found to have prognostic accuracy in identifying these patients compared with TBI patients whose ICP $\leq 20 \mathrm{mmHg}$ throughout the study period (cut-off, $140 \mu \mathrm{g} / \mathrm{mL} ; 87 \%$ sensitivity; $73 \%$ specificity). Likewise, low total serum copper $(<1.32 \mu \mathrm{g} / \mathrm{mL})$ within the first 24 -h of injury was also found to be predictive of high ICP (86\% sensitivity; $73 \%$ specificity). The combination of serum ceruloplasmin and serum copper (cut-offs, $140 \mu \mathrm{g} / \mathrm{mL}$ and 1.50 $\mu \mathrm{g} / \mathrm{mL}$, respectively) increased the specificity to $100 \%$ while maintaining a sensitivity of $67 \% .^{122}$

\section{Blood brain barrier compromise}

Loss of BBB integrity allows for the unrestricted entry of blood-borne materials into the brain and has been linked to exacerbated inflammation, increased ICP, altered homeostasis, and other pathological consequences of TBI. ${ }^{123}$ Because S100B does not cross the intact BBB, its levels in the serum (or a serum/CSF ratio) have been proposed to be an indicator of barrier integrity. To investigate this possibility, Kirchhoff et al. ${ }^{124}$ evaluated $\mathrm{S} 100 \mathrm{~B}$ in the serum of severe TBI patients to determine if its levels correlated with the presence of albumin in the CSF. This study revealed that there was a positive correlation between serum S100B levels and the degree of albumin leakage at various time points after injury.

\section{Secondary ischemia}

Secondary or delayed ischemia is another prominent pathology that influences outcome after TBI. ${ }^{125}$ Delayed ischemia can result from multiple processes, including intracranial hypertension resulting from elevated ICP, compromised cerebral pressure autoregulation, vasospasm, and/or hemorrhaging from damaged vasculature. These processes result in reduced blood flow to the injured tissue that is insufficient to meet the tissue's metabolic needs. Cardiolipin is a phospholipid that is highly enriched in the inner membrane of mitochondria, and under periods of high oxidative stress, it is oxidized and is believed to contribute to mitochondrial dysfunction and cell death. Although limited research has been done on the consequences of TBI on cardiolipin levels, there is increasing evidence that the presence of anticardiolipin antibodies may be an independent risk factor for stroke. ${ }^{126,127}$ If TBI results in the production of anticardiolipin (or other antiphospholipid) antibodies, these may serve as biomarkers for identifying those patients at risk for developing post-TBI ischemic events.

\section{Post-traumatic epilepsy}

TBI is a frequent cause of acquired epilepsy. ${ }^{128}$ Seizure activity after TBI has been categorized as immediate (i.e., within $24 \mathrm{~h}$ ); early (i.e., within 1 week) and late (i.e, $>1$-week post-injury). ${ }^{129}$ Post-traumatic epilepsy occurs in $\leq 50 \%$ of severe TBI patients, with the incidence being highest after penetrating brain injury. ${ }^{130-132}$ The Brain Trauma Foundation guidelines recommend anticonvulsants to decrease the incidence of early posttraumatic seizures, but because of adverse effects and no demonstrated improvement on outcomes, anticonvulsants are not recommended for preventing late post-trau- 
matic seizures. ${ }^{133}$ Electroencephalography, CT, and MRI (hemosiderin deposits and gliotic scarring ${ }^{134}$ ) may be used to try to predict seizures, but these methods are inadequate. Currently we do not have a method of preventing the development of late post-traumatic seizures. The apolipoprotein E epsilon 4 alele has been associated with post-traumatic seizures. ${ }^{135}$ Reductions of hippocampal NAA, a marker for viable neurons, have been shown in temporal lobe epilepsy and mesial temporal lobe sclerosis. ${ }^{136}$ Collapsin response-mediated protein-2, and proteins involved in axonal outgrowth, path finding, and maintaining neuronal polarity have been demonstrated to be down-regulated in hippocampal tissue of patients with mesial temporal lobe epilepsy. ${ }^{137}$ All of these have also been associated with other neurodegenerative disorders, such as Alzheimer's disease. Identifying biomarkers that are predictive of post-traumatic seizure development and response to medication would greatly aid in the treatment of TBI.

\section{BIOMARKERS FOR PREDICTING OUTCOME}

Some of the most disruptive symptoms experienced by TBI patients who survive their injuries are persistent memory and behavioral problems. In addition to overt memory disturbances, brain injury is associated with increased rates of depression, sleep disturbances, mood changes, impulsiveness, and an inability to extinguish fearful memories. These memory and behavioral problems can interfere with post-TBI recovery and rehabilitation. The identification of biomarkers that can be used to predict these clinical outcomes would be invaluable to identify those patients likely to benefit from a rehabilitation regimen, to inform and counsel family members regarding the prognosis, and to encourage the patient (or caretaker of the patient) to be vigilant for reporting future symptoms. This is especially important for mild TBI patients who are discharged quickly because their injuries are typically not life-threatening. Outcome predication after MTBI is dependent on proper diagnosis of the condition, especially the patients without an overt brain injury. However, recent studies are beginning to show that a significant number of these patients develop psychological and behavioral problems that can impact their family and work life.

Although several studies have used the GOS to assess the long-term association of a biomarker change with outcome, the dichotomous nature of reporting (e.g., good vs poor) makes it difficult to assess what aspect of outcome is being correlated. Nevertheless, studies are beginning to show that biomarkers (either alone or in combination) can be used to predict favorable or poor outcome. For example, high initial serum levels of S100B, NSE, GFAP, and tau have all been linked to poor outcome 6 months later. ${ }^{15,37,138,139}$ Bandyopadhyay et al. ${ }^{140}$ have reported that NSE at a cut-off value of 21.2 $\mathrm{ng} / \mathrm{mL}$ has $86 \%$ sensitivity and $74 \%$ specificity for poor outcome in pediatric patients. However, it is yet to be determined if these markers can be used to identify those patients with specific pathologies (e.g., memory disturbances) or if it can be used as surrogate markers to evaluate the effectiveness of a rehabilitation program.

\section{BIOMARKERS FOR POLYTRAUMA}

In many cases, human brain injury occurs as a part of polytrauma. The Veterans Health Administration defines polytrauma as "injury to the brain in addition to other body parts or systems resulting in physical, cognitive, psychological, or psychosocial impairments and functional disability." 141 People involved in vehicular accidents, soldiers exposed to improvised explosive devices, and (to a lesser extent) athletes involved in contacts sports often suffer from polytrauma. Multiple organ failure (MOF) and acute respiratory distress syndrome are the leading causes of death after polytrauma. "One-hit" and "two-hit" models have been proposed for MOF after severe and mild to moderate polytrauma. ${ }^{142,143}$ A severe traumatic injury is believed to elicit a systemic inflammatory response that can give rise to MOF, the one-hit model. After a less severe trauma, organs remain at a vulnerable state (possibly due to a milder inflammatory response), and a second insult can precipitate MOF, the two-hit model. Surgical procedures that are often performed on polytrauma patients can represent a second hit and can give rise to MOF. Similar to the two-hit model for MOF, the brain is highly vulnerable to a second insult such as ischemia, hypoperfusion, and repeat concussive injury. Biomarkers whose levels are indicative of the duration of vulnerability would be useful for managing polytrauma patients. This is also important for determining how long a soldier or an athlete should remain inactive to avoid a second hit. The serum levels of inflammatory biomarkers (e.g., IL-1, IL-6, TNF $\alpha$, sTNF-R p55, sTNF-R p75) have been measured in polytrauma patients, ${ }^{144-146}$ with the levels of IL-6 shown to correlate with injury severity score, acute respiratory distress syndrome, and MOF. Furthermore, the initial serum levels (days 0-1) of sTNF-R p55 and sTNF-R p75 have good predictive value ( 0.75 and 0.72 , respectively) for the development of late MOF. ${ }^{146}$

Diagnosis of TBI in polytrauma patients using current biomarkers can be challenging. As previously described, several of the putative biomarkers of injury suffer from a lack of specificity in that they can be released into the serum by conditions not due to brain injury. For example, S100B has been identified as a highly sensitive marker of brain damage. However, the levels of this protein are also increased in conditions such as ischemia to the liver, kidney, and gut, ${ }^{16}$ after extracranial trauma ${ }^{14}$ 
Table 1. Summary of TBI-Related Biomarkers and their Utility

\begin{tabular}{|c|c|c|c|c|}
\hline Biomarker & $\begin{array}{l}\text { Diagnostic Value (Cut-off: } \\
\text { Sensitivity/Specificity) }\end{array}$ & $\begin{array}{l}\text { Sample } \\
\text { Source }\end{array}$ & Comments & References \\
\hline$\alpha$-II-Spectrin BDPs & $\begin{array}{l}\uparrow \text { In TBI; correlate with lesion } \\
\text { size, injury severity }\end{array}$ & $\begin{array}{l}\text { CSF, brain } \\
\text { tissue, serum }\end{array}$ & $\begin{array}{l}\text { Brain enrichedIndicates mode of } \\
\text { death }\end{array}$ & $\begin{array}{l}35,34,153 \\
154\end{array}$ \\
\hline$\alpha$-Synuclean & $\uparrow$ In TBI & Brain tissue & Needs validation in humans & 156,157 \\
\hline C-tau & $\begin{array}{l}\uparrow \mathrm{C} \text {-tau correlated with outcome; } \\
\uparrow \mathrm{C} \text {-tau correlated with } \uparrow \mathrm{ICP} \\
1600 \mathrm{ng} / \mathrm{mL}: \text { GOS }(92 \% / 94 \%) ; \\
1500 \mathrm{ng} / \mathrm{mL}: \mathrm{ICP}(78 \% / 79 \%)\end{array}$ & CSF, serum & $\begin{array}{l}\text { Specific to CNS } \\
\text { Poor diagnostic value for mild } \\
\text { TBI }\end{array}$ & 37 \\
\hline 3',5'cAM/2',3'cAMP & $\begin{array}{l}\text { CSF level correlated with coma } \\
\text { grade }\end{array}$ & CSF & Second messenger & 72 \\
\hline Ceruloplasmin/Cu & $\begin{array}{l}\downarrow \text { In TBI patients with elevated } \\
\text { ICP }\end{array}$ & Serum & Copper can be rapidly assessed & 122 \\
\hline $\mathrm{CK}-\mathrm{BB}$ & $\begin{array}{l}\text { BBB disruption necessary for } \\
\text { serum penetration; no } \\
\text { correlation with contusion } \\
\text { volume }\end{array}$ & CSF, serum & Short half-life, rapid elimination & 27,155 \\
\hline CRP \& SAA & General injury markers & Serum & $\begin{array}{l}\text { Rapidly induced. May indicate } \\
\text { polytrauma }\end{array}$ & 8 \\
\hline CRMP-2 & $\begin{array}{l}\downarrow \text { In mesial temporal lobe of } \\
\text { epilepsy patients, associated } \\
\text { with Alzheimer's }\end{array}$ & Brain tissue & $\begin{array}{l}\text { May be a marker for post- } \\
\text { traumatic epilepsy }\end{array}$ & 137 \\
\hline FABP & Identifying mild TBI $(\uparrow)$ & $\begin{array}{l}\text { Serum/plasma, } \\
\text { brain tissue }\end{array}$ & High accuracy for mild TBI & 32 \\
\hline F2-Isoprostane & $\uparrow$ In multiple diseases & CSF, serum & Marker of oxidative damage & $81-84$ \\
\hline 4-HNE & $\uparrow$ In TBI brain tissue & Brain tissue & Marker of lipid peroxidation & 88,89 \\
\hline 5-HIAA & $\uparrow$ In CSF; indicator of trauma & $\mathrm{CSF}$ & $\begin{array}{l}\text { Marker of altered } \\
\text { neurotransmission }\end{array}$ & 75,76 \\
\hline GFAP & $\begin{array}{l}\text { Predictive of } \uparrow \text { ICP, } \downarrow \text { MAP, } \\
\downarrow \text { CPP, mortality \& GOS } \\
1.5 \mathrm{ng} / \mathrm{mL}: \\
\text { Death }(85 \% / 52 \%) \\
\text { GOS }(80 \% / 59 \%)\end{array}$ & CSF, serum & $\begin{array}{l}\text { Specific to CNS May not be } \\
\text { sensitive enough for mild TBI }\end{array}$ & 15 \\
\hline HVA & $\uparrow \operatorname{In} \mathrm{CSF}$ & CSF & $\begin{array}{l}\text { Marker of altered } \\
\text { neurotransmission }\end{array}$ & 75 \\
\hline ICAM & $\begin{array}{l}\uparrow \text { Correlates with } \uparrow \mathrm{BBB} \\
\text { compromise }\end{array}$ & CSF, serum & $\begin{array}{l}\text { Marker for neurovascular } \\
\text { dysfunction }\end{array}$ & 66 \\
\hline IL- $1 \beta$ & $\begin{array}{l}\uparrow \text { Correlates with worse } \\
\text { outcome } \\
\uparrow \text { In CSF in severe TBI }\end{array}$ & $\mathrm{CSF}$ & Development of astroglial scars & $46,47,48$ \\
\hline IL-6 & $\begin{array}{l}\text { Conflicting results. } \uparrow \text { IL-6 } \\
\text { correlates with improved } \\
\text { outcome; } \uparrow \text { peak IL-6 in } \\
\text { nonsurviors }\end{array}$ & $\begin{array}{l}\text { CSF, serum, } \\
\text { intracranial } \\
\text { dialysate }\end{array}$ & Marker for multi-organ failure & 58,59 \\
\hline IL-8 & $\uparrow$ In CSF in severe TBI & CSF, serum & Marker of inflammation & 44 \\
\hline IL-10 & $\begin{array}{l}\uparrow \text { CSF IL-10 associated with } \downarrow \\
\text { TNF- } \alpha \& \text { mortality }\end{array}$ & CSF, serum & Anti-inflammatory marker & 62,63 \\
\hline IL-12p70 & $\uparrow$ In CSF in severe TBI & CSF, serum & Marker of inflammation & 44 \\
\hline Lactate & Correlates with injury severity & CSF & $\begin{array}{l}\text { Marker for altered brain } \\
\text { metabolism }\end{array}$ & 77 \\
\hline Magnesium & $\begin{array}{l}\downarrow \text { Mg over initial } 5 \text { days related } \\
\text { to injury severity }\end{array}$ & Serum & & 152 \\
\hline MBP & $\begin{array}{l}\uparrow \text { Correlates with worse } \\
\text { outcome in children }\end{array}$ & CSF, serum & Marker for white matter injury & 30 \\
\hline MCP-1 & $\begin{array}{l}\uparrow \text { In rodent brain } 4 \text {-h post- } \\
\text { injury }\end{array}$ & Brain tissue & $\begin{array}{l}\text { Recruitment of monocytes into } \\
\text { brain; not tested in humans }\end{array}$ & 67 \\
\hline $\mathrm{MIP}-1 \alpha$ & $\uparrow$ In CSF in severe TBI & $\mathrm{CSF}$ & $\begin{array}{l}\text { Marker for inflammatory cell } \\
\text { invasion }\end{array}$ & 44 \\
\hline NAA & $\begin{array}{l}\downarrow \text { Injury marker; ratio NAA/Cre } \\
\& \text { Cho/Cre predictive of } \\
\text { deficits }\end{array}$ & & $\begin{array}{l}\text { Marker for detecting regional } \\
\text { injury by magnetic resonance } \\
\text { spectroscopy }\end{array}$ & 79,80 \\
\hline
\end{tabular}


Table 1. Continued

\begin{tabular}{|c|c|c|c|c|}
\hline Biomarker & $\begin{array}{l}\text { Diagnostic Value (Cut-off: } \\
\text { Sensitivity/Specificity) }\end{array}$ & $\begin{array}{l}\text { Sample } \\
\text { Source }\end{array}$ & Comments & References \\
\hline Phospho-neurofilament & $\uparrow$ In TBI & Serum & $\begin{array}{l}\text { Needs to be validated in } \\
\text { humans }\end{array}$ & 38 \\
\hline NSE & $\begin{array}{l}\text { Neuropsychological outcome } \\
\text { intracranial lesions } \\
21.7 \mathrm{ng} / \mathrm{mL}: \text { mortality } \\
(85 \% / 80 \%) \text { outcome }(55 \% / \\
78 \%) \\
15.3 \mathrm{ng} / \mathrm{mL}: \text { intracranial lesions } \\
(77 \% / 52 \%)\end{array}$ & $\begin{array}{l}\text { CSF, serum, } \\
\text { brain tissue }\end{array}$ & $\begin{array}{l}\text { Putative marker for small cell } \\
\text { lung cancer, neuroendocrine } \\
\text { bladder tumors, stroke, and } \\
\text { neuroblastoma }\end{array}$ & $28,29,138$ \\
\hline $\mathrm{NE}$ & $\begin{array}{l}\uparrow \text { In comatose patients; } \uparrow \\
\text { polytrauma }\end{array}$ & Serum & $\begin{array}{l}\text { Marker of altered } \\
\text { neurotransmission and stress }\end{array}$ & 74 \\
\hline S100B & $\begin{array}{l}\text { Mortality/morbidity; Mild TBI } \\
\uparrow \text { in patients with intracranial } \\
\text { injury } \\
1.13 \mathrm{ng} / \mathrm{mL}(100 \% / 41 \%) \\
1.13 \mathrm{ng} / \mathrm{mL}(88 \% / 43 \%) \\
0.10 \mu / \mathrm{L}(95 \% / 31 \%)\end{array}$ & CSF, serum & $\begin{array}{l}\text { Not selectively specific to TBI; } \\
\text { can be used as a marker of } \\
\text { BBB compromise }\end{array}$ & $15,95,139$ \\
\hline TGF- $\beta$ & $\begin{array}{l}\uparrow \text { After TBI, remains elevated } \\
\sim 3 \text { weeks }\end{array}$ & CSF & $\begin{array}{l}\text { Cell growth and differentiation, } \\
\text { angiogenesis, immune } \\
\text { function, apoptosis }\end{array}$ & 65 \\
\hline TNF- $\alpha$ & $\begin{array}{l}\uparrow \text { In severe } \mathrm{TBI} ; \uparrow \text { did not } \\
\text { correlate with mortality }\end{array}$ & CSF, serum & Marker of inflammation & 53 \\
\hline UCH-L1 & $\begin{array}{l}\uparrow \text { In CSF, correlated with } \\
\text { mortality, complications and } 6 \\
\text { month outcome }\end{array}$ & $\mathrm{CSF}$ & Brain enriched marker & 39 \\
\hline
\end{tabular}

\begin{abstract}
$\downarrow=$ decreased/downregulated; $\uparrow=$ increased/upregulated; BBB = blood brain barrier; BDPs = proteolytic breakdown products; B-FABP = brain type-fatty acid binding proteins; $\mathrm{C}$-tau $=$ cleaved tau; $\mathrm{Cho} / \mathrm{Cre}=$ choline/creatine; $\mathrm{CK}-\mathrm{BB}=$ creatine kinase-BB; $\mathrm{CPP}=$ cerebral perfusion pressure; CRMP-2 = collapsin response mediated protein-2; CRP $=$ C-reactive protein; FABP $=$ fatty acid binding proteins; GCS = Glasgow coma score; GDNF = glial derived neurotrophic factor; GFAP = glial fibrillary acidic protein; GOS = Glasgow outcome scale; 5-HIAA = 5-hydroxy indol acetic acid; HNE = 4-Hydroxynonenal; HVA = homovanillic acid; ICAM = intercellular adhesion molecule 1; ICP = intracranial pressure; IL = interleukin; MAP = mean arterial pressure; MBP = myelin basic protein; MCP-1 = monocyte chemo-attractant protein-1; MIP = macrophage inflammatory protein; NAA $=\mathrm{N}$-acetylaspartate; $\mathrm{NE}=$ norepinephrine; $\mathrm{NSE}=$ neuron-specific enolase; phospho-NFH $=$ phosphorylated neurofilament $\mathrm{H}$; TBI $=$ traumatic brain injury; TGF- $\beta=$ transforming growth factor-beta; TNF- $\alpha=$ tumor necrosis factor-alpha; UCH-L1 = ubiquitin C-terminal hydrolase.
\end{abstract}

and burns. ${ }^{17}$ Based on these reports, S100B may not have strong diagnostic value in the context of multi-trauma. da Rocha et al. ${ }^{147}$ evaluated serum levels of S100B in TBI patients either with or without trauma to other organs. They found that S100B remained a strong predictor of mortality after TBI, irrespective of multi-trauma.

Although it appears that S100B may have prognostic value in identifying those patients for whom survival is doubtful, it remains a challenge to identify mild brain trauma in the context of other bodily injuries. For example, GFAP, although highly specific to brain injury and therefore less likely to be influenced by other bodily injuries, ${ }^{24}$ has not been proven to be sensitive enough to detect mild TBI. Serum levels of BDPs of brain-specific proteins may be useful in diagnosing TBI in polytrauma patients. A single biomarker may not be able to diagnose polytrauma nor indicate which organs are injured. However, changes in multiple proteins may provide the sensitivity and specificity required to diagnose different types of polytrauma. For example, a combination of biomarkers from multiple disease pathways (troponin I [myocardial cell damage], $\mathrm{N}$ - terminal prohormone brain natriuretic peptide [left ventricular dysfunction], C-reactive protein [inflammation], and cystatin $\mathrm{C}$ [renal failure]) improved risk stratification for death from cardiovascular causes among elderly men. ${ }^{148}$ Therefore, continued research is required to identify specific and sensitive biological markers of brain damage when used in combination with markers of other organ damage (e.g., troponin and creatine phosphokinase isoenzyme MB [CPK-MB] for heart; aspartate, and alanine transaminases for liver; lipases for pancreas; blood urea nitrogen and creatinine for kidney), which can assist the physician in identifying the organs damaged as a result of polytrauma.

\section{FUTURE DIRECTIONS}

Although several biomarkers of brain injury have been identified, as summarized in Table 1, continued research is required. These markers can take on many forms, with proteins, peptides, lipids, and small molecules having been shown to have diagnostic and prognostic value. However, several of these markers suffer from a lack of 
specificity, often being induced or released into the serum in response to other diseases or bodily injuries. This lack of specificity has hampered the effort to identify markers of mild TBI, especially in the context of polytrauma. A single biomarker may not have desired sensitivity and specificity for diagnosis nor for predicting outcome. Biomarkers, in combination with other clinical data, such as GCS and head CT scan, would maximize the diagnostic accuracy. Su and Liu ${ }^{149}$ have provided a theoretical framework for the optimal, linear combination of biomarkers that maximizes the area under the receiver operator characteristic curve. Modifications to this liner combination approach (e.g., in which sensitivity is maximized instead of the area over a range of specificity) have also been described. ${ }^{150}$ Another method that could be used to overcome this problem is by applying boosting algorithms. ${ }^{151}$ Boosting occurs in stages, during each of which a weak predictor (e.g., a biomarker that has a low specificity) is trained with the data. The output of the weak learner is then weighted (proportional to the accuracy of the weak predictor) and added to the overall function. The data is then re-weighted so that patients who are misidentified are "boosted" in importance. New biomarkers are trained and added to attempt to correct the misclassifications. One advantage of this technique is that the biomarkers do not need to be biological in nature, but can be the result of neurologic examinations, imaging, physiological measurements, or other diagnostic tests. With continued research it may be possible to find biomarkers that not only predict secondary pathologies, such as elevated intracranial pressure, but also those that can identify patients at risk for adverse long-term outcomes, such as memory loss, depression, and post-traumatic stress disorder. Because these pathologies depend on different brain structures and cell types, it is likely that a single biomarker will not be able to accurately predict which patients are at risk for their occurrence. Future studies will be required to not only identify these biomarkers, but to develop a clinically useful test in which a panel of TBI-associated biomarkers (a biomarker signature) are evaluated and used to direct treatment.

Acknowledgments: The authors would like to thank Drs. Jordan Clark and Dan Johnson for their critical reading of the manuscript. We also thank a grant sponsored by the National Institutes of Health, The Mission Connect/TIRR Foundation (Grant No.s: NS35457, NS049160, MH072933, CDMRP: W81XWH-08-2-0134, and R38OT10585).

\section{REFERENCES}

1. Hoge CW, Castro CA, Messer SC, McGurk D, Cotting DI, Koffman RL. Combat duty in Iraq and Afghanistan, mental health problems, and barriers to care. N Engl J Med 2004;351:13-22.

2. Okie S. Traumatic brain injury in the war zone. N Engl J Med 2005;352:2043-2047.
3. Holcomb JB, Stansbury LG, Champion HR, Wade C, Bellamy RF. Understanding combat casualty care statistics. J Trauma 2006;60:397-401.

4. Kochanek PM, Clark RS, Ruppel RA, et al. Biochemical, cellular, and molecular mechanisms in the evolution of secondary damage after severe traumatic brain injury in infants and children: Lessons learned from the bedside. Pediatr Crit Care Med 2000;1:4-19.

5. Liu MC, Akle V, Zheng W, et al. Comparing calpain- and caspase-3-mediated degradation patterns in traumatic brain injury by differential proteome analysis. Biochem J 2006;394:715-725.

6. Colicos MA, Dixon CE, Dash PK. Delayed, selective neuronal death following experimental cortical impact injury in rats: possible role in memory deficits. Brain Res 1996;739:111-119.

7. Colicos MA, Dash PK. Apoptotic morphology of dentate gyrus granule cells following experimental cortical impact injury in rats: possible role in spatial memory deficits. Brain Res 1996;739:120 131.

8. Hergenroeder G, Redell JB, Moore AN, et al. Identification of serum biomarkers in brain-injured adults: potential for predicting elevated intracranial pressure. J Neurotrauma 2008;25:79-93.

9. States DJ, Omenn GS, Blackwell TW, et al. Challenges in deriving high-confidence protein identifications from data gathered by a HUPO plasma proteome collaborative study. Nat Biotechnol 2006;24:333-338.

10. Gao J, Garulacan LA, Storm SM, et al. Biomarker discovery in biological fluids. Methods 2005;35:291-302.

11. Petricoin EE, Paweletz CP, Liotta LA. Clinical applications of proteomics: proteomic pattern diagnostics. J Mammary Gland Biol Neoplasia 2002;7:433-440.

12. Haskins WE, Kobeissy FH, Wolper RA, et al. Rapid discovery of putative protein biomarkers of traumatic brain injury by SDSPAGE-capillary liquid chromatography-tandem mass spectrometry. J Neurotrauma 2005;22:629-644.

13. Unden $\mathrm{J}$, Astrand $\mathrm{R}$, Waterloo $\mathrm{K}$, et al. Clinical significance of serum S100B levels in neurointensive care. Neurocrit Care 2007;6: 94-99.

14. Savola O, Pyhtinen J, Leino TK, Siitonen S, Niemela O, Hillbom M. Effects of head and extracranial injuries on serum protein S100B levels in trauma patients. J Trauma 2004;56:1229-1234.

15. Vos PE, Lamers KJ, Hendriks JC, et al. Glial and neuronal proteins in serum predict outcome after severe traumatic brain injury. Neurology 2004;62:1303-1310.

16. Pelinka LE, Harada N, Szalay L, Jafarmadar M, Redl H, Bahrami S. Release of S100B differs during ischemia and reperfusion of the liver, the gut, and the kidney in rats. Shock 2004;21:72-76.

17. Anderson RE, Hansson LO, Nilsson O, Dijlai-Merzoug R, Settergren G. High serum S100B levels for trauma patients without head injuries. Neurosurgery 2001;48:1255-1258.

18. Torabian S, Kashani-Sabet M. Biomarkers for melanoma. Curr Opin Oncol 2005;17:167-171.

19. Piazza O, Storti MP, Cotena S, et al. S100B is not a reliable prognostic index in pediatric TBI. Pediatr Neurosurg 2007;43:258-264.

20. Berger RP, Adelson PD, Pierce MC, Dulani T, Cassidy LD, Kochanek PM. Serum neuron-specific enolase, S100B, and myelin basic protein concentrations after inflicted and noninflicted traumatic brain injury in children. J Neurosurg 2005;103:61-68.

21. Berger RP, Beers SR, Richichi R, Wiesman D, Adelson PD. Serum biomarker concentrations and outcome after pediatric traumatic brain injury. J Neurotrauma 2007;24:1793-1801.

22. Missler U, Wiesmann M, Wittmann G, Magerkurth O, Hagenström H. Measurement of glial fibrillary acidic protein in human blood: analytical method and preliminary clinical results. Clin Chem 1999;45:138-141.

23. Nylen K, Ost M, Csajbok LZ, et al. Increased serum-GFAP in patients with severe traumatic brain injury is related to outcome. J Neurol Sci 2006;240:85-91.

24. Pelinka LE, Kroepfl A, Schmidhammer R, et al. Glial fibrillary acidic protein in serum after traumatic brain injury and multiple trauma. J Trauma 2004;57:1006-1012.

25. Herrmann M, Jost S, Kutz S, et al. Temporal profile of release of neurobiochemical markers of brain damage after traumatic brain injury is associated with intracranial pathology as dem- 
onstrated in cranial computerized tomography. J Neurotrauma 2000;17:113-122.

26. Ross SA, Cunningham RT, Johnston CF, Rowlands BJ. Neuronspecific enolase as an aid to outcome prediction in head injury. Br J Neurosurg 1996;10:471-476.

27. Skogseid IM, Nordby HK, Urdal P, Paus E, Lilleaas F. Increased serum creatine kinase BB and neuron specific enolase following head injury indicates brain damage. Acta Neurochir (Wien) 1992; 115:106-111.

28. Fridriksson T, Kini N, Walsh-Kelly C, Hennes H. Serum neuronspecific enolase as a predictor of intracranial lesions in children with head trauma: a pilot study. Acad Emerg Med 2000;7:816-820.

29. Herrmann M, Curio N, Jost S, et al. Release of biochemical markers of damage to neuronal and glial brain tissue is associated with short and long term neuropsychological outcome after traumatic brain injury. J Neurol Neurosurg Psychiatry 2001;70:95-100.

30. Berger RP, Adelson PD, Pierce MC, Dulani T, Cassidy LD, Kochanek PM. Serum neuron-specific enolase, S100B, and myelin basic protein concentrations after inflicted and noninflicted traumatic brain injury in children. J Neurosurg 2005;103:61-68.

31. Glatz JF, van der Vusse GJ. Cellular fatty acid-binding proteins: their function and physiological significance. Prog Lipid Res 1996;35:243-282.

32. Pelsers MM, Hanhoff T, Van der Voort D, et al. Brain- and heart-type fatty acid-binding proteins in the brain: tissue distribution and clinical utility. Clin Chem 2004;50:1568-1575.

33. Gabbita SP, Scheff SW, Menard RM, Roberts K, Fugaccia I, Zemlan FP. Cleaved-tau: a biomarker of neuronal damage after traumatic brain injury. J Neurotrauma 2005;22:83-94.

34. Wang KK, Ottens AK, Liu MC, et al. Proteomic identification of biomarkers of traumatic brain injury. Expert Rev Proteomics 2005;2:603-614.

35. Ringger NC, O'Steen BE, Brabham JG, et al. A novel marker for traumatic brain injury: CSF alphaII-spectrin breakdown product levels. J Neurotrauma 2004;21:1443-1456.

36. Cardali S, Maugeri R. Detection of alphaII-spectrin and breakdown products in humans after severe traumatic brain injury. J Neurosurg Sci 2006;50:25-31.

37. Zemlan FP, Jauch EC, Mulchahey JJ, et al. C-tau biomarker of neuronal damage in severe brain injured patients: association with elevated intracranial pressure and clinical outcome. Brain Res 2002;947:131-139.

38. Anderson KJ, Scheff SW, Miller KM, et al. The phosphorylated axonal form of the neurofilament subunit NF-H (pNF-H) as a blood biomarker of traumatic brain injury. J Neurotrauma 2008; 25:1079-1085.

39. Papa L, Akinyi L, Liu MC, et al. Ubiquitin C-terminal hydrolase is a novel biomarker in humans for severe traumatic brain injury. Crit Care Med 2009 Sep 1 [Epub ahead of print].

40. Morganti-Kossmann MC, Rancan M, Otto VI, Stahel PF, Kossmann T. Role of cerebral inflammation after traumatic brain injury: a revisited concept. Shock 2001;16:165-177.

41. Allan SM, Rothwell NJ. Cytokines and acute neurodegeneration. Nat Rev Neurosci 2001;2:734-744.

42. Kadhim HJ, Duchateau J, Sebire G. Cytokines and brain injury: invited review. J Intensive Care Med 2008;23:236-249.

43. Whitney NP, Eidem TM, Peng H, Huang Y, Zheng JC. Inflammation mediates varying effects in neurogenesis: relevance to the pathogenesis of brain injury and neurodegenerative disorders. J Neurochem 2009;108:1343-1359.

44. Buttram SD, Wisniewski SR, Jackson EK, et al. Multiplex assessment of cytokine and chemokine levels in cerebrospinal fluid following severe pediatric traumatic brain injury: effects of moderate hypothermia. J Neurotrauma 2007;24:1707-1717.

45. Berger RP, Dulani T, Adelson PD, Leventhal JM, Richichi R, Kochanek PM. Identification of inflicted traumatic brain injury in well-appearing infants using serum and cerebrospinal markers: a possible screening tool. Pediatrics 2006;117:325-332.

46. Giulian D, Lachman LB. Interleukin-1 stimulation of astroglial proliferation after brain injury. Science 1985;228:497-499.

47. Singhal A, Baker AJ, Hare GM, Reinders FX, Schlichter LC, Moulton RJ. Association between cerebrospinal fluid interleu- kin- 6 concentrations and outcome after severe human traumatic brain injury. J Neurotrauma 2002;19:929-937.

48. Chiaretti A, Genovese O, Aloe L, et al. Interleukin 1beta and interleukin 6 relationship with paediatric head trauma severity and outcome. Childs Nerv Syst 2005;21:185-193.

49. Brenner T, Yamin A, Abramsky O, Gallily R. Stimulation of tumor necrosis factor-alpha production by mycoplasmas and inhibition by dexamethasone in cultured astrocytes. Brain Res 1993;608:273-279.

50. Sawada M, Kondo N, Suzumura A, Marunouchi T. Production of tumor necrosis factor-alpha by microglia and astrocytes in culture. Brain Res 1989;491:394-397.

51. Mier JW, Vachino G, van der Meer JW, et al. Induction of circulating tumor necrosis factor (TNF alpha) as the mechanism for the febrile response to interleukin-2 (IL-2) in cancer patients. J Clin Immunol 1988;8:426-436.

52. Shohami E, Gallily R, Mechoulam R, Bass R, Ben-Hur T. Cytokine production in the brain following closed head injury: dexanabinol (HU-211) is a novel TNF-alpha inhibitor and an effective neuroprotectant. J Neuroimmunol 1997;72:169-177.

53. Crespo AR, Da Rocha AB, Jotz GP, et al. Increased serum sFas and TNFalpha following isolated severe head injury in males. Brain Inj 2007;21:441-447.

54. Goodman JC, Robertson CS, Grossman RG, Narayan RK. Elevation of tumor necrosis factor in head injury. J Neuroimmunol 1990;30:213-217.

55. Ross SA, Halliday MI, Campbell GC, Byrnes DP, Rowlands BJ. The presence of tumour necrosis factor in CSF and plasma after severe head injury. Br J Neurosurg 1994;8:419-425.

56. Kossmann T, Hans V, Imhof HG, Trentz O, Morganti-Kossmann MC. Interleukin-6 released in human cerebrospinal fluid following traumatic brain injury may trigger nerve growth factor production in astrocytes. Brain Res 1996;713:143-152.

57. Minambres E, Cemborain A, Sanchez-Velasco P, et al. Correlation between transcranial interleukin- 6 gradient and outcome in patients with acute brain injury. Crit Care Med 2003;31:933-938.

58. Winter CD, Pringle AK, Clough GF, Church MK. Raised parenchymal interleukin-6 levels correlate with improved outcome after traumatic brain injury. Brain 2004;127:315-320.

59. Chiaretti A, Antonelli A, Mastrangelo A, et al. Interleukin-6 and nerve growth factor upregulation correlates with improved outcome in children with severe traumatic brain injury. J Neurotrauma 2008;25:225-234.

60. Aibiki M, Maekawa S, Nishiyama T, Seki K, Yokono S. Activated cytokine production in patients with accidental hypothermia. Resuscitation 1999;41:263-268.

61. Morganti-Kossmann MC, Rancan M, Stahel PF, Kossmann T. Inflammatory response in acute traumatic brain injury: a doubleedged sword. Curr Opin Crit Care 2002;8:101-105.

62. Csuka E, Morganti-Kossmann MC, Lenzlinger PM, Joller H, Trentz O, Kossmann T. IL-10 levels in cerebrospinal fluid and serum of patients with severe traumatic brain injury: relationship to IL-6, TNF-alpha, TGF-beta1 and blood-brain barrier function. J Neuroimmunol 1999;101:211-221.

63. Bell MJ, Kochanek PM, Doughty LA, et al. Comparison of the interleukin- 6 and interleukin- 10 response in children after severe traumatic brain injury or septic shock. Acta Neurochir Suppl (Wien) 1997;70:96-97.

64. Attisano L, Wrana JL, Lopez-Casillas F, Massague J. TGF-beta receptors and actions. Biochim Biophys Acta 1994;1222:71-80.

65. Morganti-Kossmann MC, Hans VH, Lenzlinger PM, et al. TGFbeta is elevated in the CSF of patients with severe traumatic brain injuries and parallels blood-brain barrier function. J Neurotrauma 1999;16:617-628.

66. Pleines UE, Stover JF, Kossmann T, Trentz O, Morganti-Kossmann MC. Soluble ICAM-1 in CSF coincides with the extent of cerebral damage in patients with severe traumatic brain injury. J Neurotrauma 1998;15:399-409.

67. Bye N, Habgood MD, Callaway JK, et al. Transient neuroprotection by minocycline following traumatic brain injury is associated with attenuated microglial activation but no changes in cell apoptosis or neutrophil infiltration. Exp Neurol 2007;204:220-233.

68. Palmer AM, Marion DW, Botscheller ML, Bowen DM, DeKosky 
ST. Increased transmitter amino acid concentration in human ventricular CSF after brain trauma. Neuroreport 1994;6:153-156.

69. Reinert M, Khaldi A, Zauner A, Doppenberg E, Choi S, Bullock R. High level of extracellular potassium and its correlates after severe head injury: relationship to high intracranial pressure. J Neurosurg 2000;93:800-807.

70. Kochanek PM, Berger RP, Bayir H, Wagner AK, Jenkins LW, Clark RS. Biomarkers of primary and evolving damage in traumatic and ischemic brain injury: diagnosis, prognosis, probing mechanisms, and therapeutic decision making. Curr Opin Crit Care 2008;14:135-141.

71. Goodman JC, Robertson CS. Microdialysis: is it ready for prime time? Curr Opin Crit Care 2009;15:110-117.

72. Rudman D, Fleischer A, Kutner MH. Concentration of $3^{\prime}, 5^{\prime}$ cyclic adenosine monophosphate in ventricular cerebrospinal fluid of patients with prolonged coma after head trauma or intracranial hemorrhage. N Engl J Med 1976;295:635-638.

73. Fleischer AS, Rudman DR, Fresh CB, Tindall GT. Concentration of $3^{\prime}, 5^{\prime}$ cyclic adenosine monophosphate in ventricular CSF of patients following severe head trauma. J Neurosurg 1977;47:517-524.

74. Clifton GL, Ziegler MG, Grossman RG. Circulating catecholamines and sympathetic activity after head injury. Neurosurgery 1981;8: $10-14$.

75. Porta M, Bareggi SR, Collice M, et al. Homovanillic acid and 5-hydroxyindole-acetic acid in the csf of patients after a severe head injury. II. Ventricular csf concentrations in acute brain posttraumatic syndromes. Eur Neurol 1975;13:545-554.

76. Inagawa $\mathrm{T}$, Ishikawa $\mathrm{S}$, Uozumi $\mathrm{T}$. Homovanillic acid and 5-hydroxyindoleacetic acid in the ventricular CSF of comatose patients with obstructive hydrocephalus. J Neurosurg 1980;52:635-641.

77. Czernicki Z, Grochowski W. [Cerebrospinal fluid lactates following craniocerebral injuries]. Neurol Neurochir Pol 1976;10:651-653.

78. Soukup J, Zauner A, Doppenberg EM, et al. Relationship between brain temperature, brain chemistry and oxygen delivery after severe human head injury: the effect of mild hypothermia. Neurol Res 2002;24:161-168.

79. Narayanan S, De SN, Francis GS, et al. Axonal metabolic recovery in multiple sclerosis patients treated with interferon beta- $1 \mathrm{~b}$. J Neurol 2001;248:979-986.

80. Yeo RA, Phillips JP, Jung RE, Brown AJ, Campbell RC, Brooks WM. Magnetic resonance spectroscopy detects brain injury and predicts cognitive functioning in children with brain injuries. J Neurotrauma 2006;23:1427-1435.

81. Montuschi P, Barnes PJ, Roberts LJ. Isoprostanes: markers and mediators of oxidative stress. FASEB J 2004;18:1791-1800.

82. Bayir H, Adelson PD, Wisniewski SR, et al. Therapeutic hypothermia preserves antioxidant defenses after severe traumatic brain injury in infants and children. Crit Care Med 2009;37:689-695.

83. Seifman MA, Adamides AA, Nguyen PN, et al. Endogenous melatonin increases in cerebrospinal fluid of patients after severe traumatic brain injury and correlates with oxidative stress and metabolic disarray. J Cereb Blood Flow Metab 2008;28:684-696.

84. Wagner AK, Bayir H, Ren D, Puccio A, Zafonte RD, Kochanek PM. Relationships between cerebrospinal fluid markers of excitotoxicity, ischemia, and oxidative damage after severe TBI: the impact of gender, age, and hypothermia. J Neurotrauma 2004;21: $125-136$.

85. Varma S, Janesko KL, Wisniewski SR, et al. F2-isoprostane and neuron-specific enolase in cerebrospinal fluid after severe traumatic brain injury in infants and children. J Neurotrauma 2003; 20:781-786.

86. Bayir H, Marion DW, Puccio AM, et al. Marked gender effect on lipid peroxidation after severe traumatic brain injury in adult patients. J Neurotrauma 2004;21:1-8.

87. Poli G, Schaur RJ, Siems WG, Leonarduzzi G. 4-hydroxynonenal: a membrane lipid oxidation product of medicinal interest. Med Res Rev 2008;28:569-631.

88. Hall ED, Detloff MR, Johnson K, Kupina NC. Peroxynitritemediated protein nitration and lipid peroxidation in a mouse model of traumatic brain injury. J Neurotrauma 2004;21:9-20.

89. Singh IN, Sullivan PG, Deng Y, Mbye LH, Hall ED. Time course of post-traumatic mitochondrial oxidative damage and dysfunction in a mouse model of focal traumatic brain injury: implica- tions for neuroprotective therapy. J Cereb Blood Flow Metab 2006;26:1407-1418.

90. Singh IN, Sullivan PG, Hall ED. Peroxynitrite-mediated oxidative damage to brain mitochondria: Protective effects of peroxynitrite scavengers. J Neurosci Res 2007;85:2216-2223.

91. Markesbery WR, Carney JM. Oxidative alterations in Alzheimer's disease. Brain Pathol 1999;9:133-146.

92. Smith RG, Henry YK, Mattson MP, Appel SH. Presence of 4-hydroxynonenal in cerebrospinal fluid of patients with sporadic amyotrophic lateral sclerosis. Ann Neurol 1998;44:696-699.

93. Agre P. Molecular physiology of water transport: aquaporin nomenclature workshop. Mammalian aquaporins. Biol Cell 1997; 89:255-257.

94. Dikmen SS, Temkin NR, Machamer JE, Holubkov AL, Fraser RT, Winn HR. Employment following traumatic head injuries. Arch Neurol 1994;51:177-186.

95. Muller K, Townend W, Biasca N, et al. S100B serum level predicts computed tomography findings after minor head injury. J Trauma 2007;62:1452-1456.

96. Unden J, Romner B. A new objective method for CT triage after minor head injury—serum S100B. Scand J Clin Lab Invest 2009; 69:13-17.

97. Bazarian JJ, Beck C, Blyth B, von AN, Hasselblatt M. Impact of creatine kinase correction on the predictive value of $\mathrm{S}-100 \mathrm{~B}$ after mild traumatic brain injury. Restor Neurol Neurosci 2006;24: 163-172.

98. Ingebrigtsen T, Romner B, Marup-Jensen S, et al. The clinical value of serum S-100 protein measurements in minor head injury: a Scandinavian multicentre study. Brain Inj 2000;14:1047-1055.

99. Nygren De BC, Fredman P, Lundin A, Andersson K, Edman G, Borg J. S100 in mild traumatic brain injury. Brain Inj 2004;18: 671-683.

100. Ingebrigtsen $T$, Romner B. Biochemical serum markers for brain damage: a short review with emphasis on clinical utility in mild head injury. Restor Neurol Neurosci 2003;21:171-176.

101. de Kruijk JR, Leffers P, Menheere PP, Meerhoff S, Twijnstra A. S-100B and neuron-specific enolase in serum of mild traumatic brain injury patients. A comparison with health controls. Acta Neurol Scand 2001;103:175-179.

102. Kavalci C, Pekdemir M, Durukan P, et al. The value of serum tau protein for the diagnosis of intracranial injury in minor head trauma. Am J Emerg Med 2007;25:391-395.

103. Bazarian JJ, Zemlan FP, Mookerjee S, Stigbrand T. Serum S-100B and cleaved-tau are poor predictors of long-term outcome after mild traumatic brain injury. Brain Inj 2006;20:759-765.

104. Vasterling JJ, Duke LM, Brailey K, Constans JI, Allain AN Jr., Sutker PB. Attention, learning, and memory performances and intellectual resources in Vietnam veterans: PTSD and no disorder comparisons. Neuropsychology 2002;16:5-14.

105. Weiss SJ. Neurobiological alterations associated with traumatic stress. Perspect Psychiatr Care 2007;43:114-122.

106. Kitayama N, Vaccarino V, Kutner M, Weiss P, Bremner JD. Magnetic resonance imaging (MRI) measurement of hippocampal volume in posttraumatic stress disorder: a meta-analysis. J Affect Disord 2005;88:79-86.

107. Smith ME. Bilateral hippocampal volume reduction in adults with post-traumatic stress disorder: a meta-analysis of structural MRI studies. Hippocampus 2005; 15:798-807.

108. Gilbertson MW, Shenton ME, Ciszewski A, et al. Smaller hippocampal volume predicts pathologic vulnerability to psychological trauma. Nat Neurosci 2002;5:1242-1247.

109. Phillips RG, LeDoux JE. Differential contribution of amygdala and hippocampus to cued and contextual fear conditioning. Behav Neurosci 1992;106:274-285.

110. Koren D, Hemel D, Klein E. Injury increases the risk for PTSD: an examination of potential neurobiological and psychological mediators. CNS Spectr 2006;11:616-624.

111. Yehuda R, Flory JD, Southwick S, Charney DS. Developing an agenda for translational studies of resilience and vulnerability following trauma exposure. Ann N Y Acad Sci 2006;1071:379-396.

112. Buckley TC, Kaloupek DG. A meta-analytic examination of basal cardiovascular activity in posttraumatic stress disorder. Psychosom Med 2001;63:585-594. 
113. Shalev AY, Sahar T, Freedman S, et al. A prospective study of heart rate response following trauma and the subsequent development of posttraumatic stress disorder. Arch Gen Psychiatry 1998;55:553-559.

114. Yehuda R, Brand SR, Golier JA, Yang RK. Clinical correlates of DHEA associated with post-traumatic stress disorder. Acta Psychiatr Scand 2006;114:187-193.

115. Rasmusson AM, Vasek J, Lipschitz DS, et al. An increased capacity for adrenal DHEA release is associated with decreased avoidance and negative mood symptoms in women with PTSD. Neuropsychopharmacology 2004;29:1546-1557.

116. Bell RS, Vo AH, Neal CJ, et al. Military traumatic brain and spinal column injury: a 5-year study of the impact blast and other military grade weaponry on the central nervous system. J Trauma 2009;66:S104-S111.

117. Yao C, Williams AJ, Ottens AK, et al. Detection of protein biomarkers using high-throughput immunoblotting following focal ischemic or penetrating ballistic-like brain injuries in rats. Brain Inj 2008;22:723-732.

118. Treggiari MM, Schutz N, Yanez ND, Romand JA. Role of intracranial pressure values and patterns in predicting outcome in traumatic brain injury: a systematic review. Neurocrit Care 2007; 6:104-112.

119. Hlatky R, Valadka AB, Robertson CS. Intracranial hypertension and cerebral ischemia after severe traumatic brain injury. Neurosurg Focus 2003;14:e2.

120. Pelinka LE, Kroepfl A, Leixnering M, Buchinger W, Raabe A, Redl H. GFAP versus S100B in serum after traumatic brain injury: relationship to brain damage and outcome. J Neurotrauma 2004;21:1553-1561.

121. Hellman NE, Gitlin JD. Ceruloplasmin metabolism and function. Annu Rev Nutr 2002;22:439-458.

122. Dash PK, Redell JB, Hergenroeder GW, Zhao J, Clifton GL, Moore AN. Serum ceruloplasmin and copper are early biomarkers of elevated intracranial pressure. J Neurosci Res 2009(in press).

123. Habgood MD, Bye N, Dziegielewska KM, et al. Changes in blood-brain barrier permeability to large and small molecules following traumatic brain injury in mice. Eur J Neurosci 2007; 25:231-238.

124. Kirchhoff C, Buhmann S, Braunstein V, et al. Cerebrospinal s100-B: a potential marker for progressive intracranial hemorrhage in patients with severe traumatic brain injury. Eur J Med Res 2008;13:511-516.

125. Signorini DF, Andrews PJ, Jones PA, Wardlaw JM, Miller JD. Adding insult to injury: the prognostic value of early secondary insults for survival after traumatic brain injury. J Neurol Neurosurg Psychiatry 1999;66:26-31.

126. Orefice G, Ames PR, Coppola M, Campanella G. Antiphospholipid antibodies and cerebrovascular disease. Acta Neurol (Napoli) 1993;15:303-310.

127. Brey RL. Antiphospholipid antibodies in young adults with stroke. J Thromb Thrombolysis 2005;20:105-112.

128. Agrawal A, Timothy J, Pandit L, Manju M. Post-traumatic epilepsy: an overview. Clin Neurol Neurosurg 2006;108:433-439.

129. Lowenstein DH. Epilepsy after head injury: an overview. Epilepsia 2009;50(suppl 2):4-9.

130. Temkin NR, Haglund MM, Winn HR. Causes, prevention, and treatment of post-traumatic epilepsy. New Horiz 1995;3:518-522.

131. Lowenstein DH. Epilepsy after head injury: an overview. Epilepsia 2009;50(suppl 2):4-9.

132. Annegers JF, Hauser WA, Coan SP, Rocca WA. A populationbased study of seizures after traumatic brain injuries. $\mathrm{N}$ Engl J Med 1998;338:20-24.

133. Bratton SL, Chestnut RM, Ghajar J, et al. Guidelines for the management of severe traumatic brain injury. XIII. Antiseizure prophylaxis. J Neurotrauma 2007;24(suppl 1):S83-S86.

134. Kumar R, Gupta RK, Husain M, et al. Magnetization transfer MR imaging in patients with posttraumatic epilepsy. AJNR Am J Neuroradiol 2003;24:218-224.

135. Diaz-Arrastia R, Gong Y, Fair S, et al. Increased risk of late posttraumatic seizures associated with inheritance of APOE epsilon4 allele. Arch Neurol 2003;60:818-822.

136. Schuff N, Meyerhoff DJ, Mueller S, et al. N-acetylaspartate as a marker of neuronal injury in neurodegenerative disease. Adv Exp Med Biol 2006;576:241-262.

137. Czech T, Yang JW, Csaszar E, Kappler J, Baumgartner C, Lubec G. Reduction of hippocampal collapsin response mediated protein-2 in patients with mesial temporal lobe epilepsy. Neurochem Res 2004;29:2189-2196.

138. Raabe A, Grolms C, Keller M, Dohnert J, Sorge O, Seifert V. Correlation of computed tomography findings and serum brain damage markers following severe head injury. Acta Neurochir (Wien) 1998;140:787-791.

139. Liliang PC, Liang CL, Weng $\mathrm{HC}$, et al. tau proteins in serum predict outcome after severe traumatic brain injury. J Surg Res 2009 Jan 10 [Epub ahead of print].

140. Bandyopadhyay S, Hennes H, Gorelick MH, Wells RG, WalshKelly CM. Serum neuron-specific enolase as a predictor of shortterm outcome in children with closed traumatic brain injury. Acad Emerg Med 2005;12:732-738.

141. Department of Veterans Affairs, Veterans Health Administration Directive, Polytrauma Rehabilitation Centers. Veterans Health Administration. Washington DC, 2005:2

142. Pape HC, Giannoudis P, Krettek C. The timing of fracture treatment in polytrauma patients: relevance of damage control orthopedic surgery. Am J Surg 2002;183:622-629.

143. Rotstein OD. Modeling the two-hit hypothesis for evaluating strategies to prevent organ injury after shock/resuscitation. J Trauma 2003;54:S203-S206.

144. Keel M, Mica L, Stover J, Stocker R, Trentz O, Harter L. Thiopental-induced apoptosis in lymphocytes is independent of CD95 activation. Anesthesiology 2005;103:576-584.

145. Bose D, Tejwani NC. Evolving trends in the care of polytrauma patients. Injury 2006;37:20-28.

146. Maier B, Lefering R, Lehnert M, et al. Early versus late onset of multiple organ failure is associated with differing patterns of plasma cytokine biomarker expression and outcome after severe trauma. Shock 2007;28:668-674.

147. da Rocha AB, Schneider RF, de Freitas GR, et al. Role of serum $\mathrm{S} 100 \mathrm{~B}$ as a predictive marker of fatal outcome following isolated severe head injury or multitrauma in males. Clin Chem Lab Med 2006;44:1234-1242.

148. Zethelius B, Berglund L, Sundstrom J, et al. Use of multiple biomarkers to improve the prediction of death from cardiovascular causes. N Engl J Med 2008;358:2107-2116.

149. Su JQ, Liu J. Linear combinations of multiple diagnostic markers. J Am Stat Assoc 1993;88:1350-1355.

150. Liu A, Schisterman EF, Zhu Y. On linear combinations of biomarkers to improve diagnostic accuracy. Stat Med 2005;24: $37-47$.

151. Qu Y, Adam BL, Yasui Y, et al. Boosted decision tree analysis of surface-enhanced laser desorption/ionization mass spectral serum profiles discriminates prostate cancer from noncancer patients. Clin Chem 2002;48:1835-1843.

152. Kahraman S, Ozgurtas T, Kayali H, et al. Monitoring of serum ionized magnesium in neurosurgical intensive care unit: preliminary results. Clin Chim Acta 2003;334:211-215.

153. Ringger NC, O'Steen BE, Brabham JG, et al. A novel marker for traumatic brain injury: CSF alphaII-spectrin breakdown product levels. J Neurotrauma 2004;21:1443-1456.

154. Pineda JA, Lewis SB, Valadka AB, et al. Clinical significance of alpha II-spectrin breakdown products in cerebrospinal fluid after severe traumatic brain injury. J Neurotrauma 2007;24:354-366.

155. Schwartz JG, Baxan III C, Gage CL, et al. Serum creatine kinase isoenzyme $\mathrm{BB}$ is a poor index to the size of various brain lesions. Clin Chem 1989;35:651-654.

156. Smith DH, Uryu K, Saatman KE, et al. Protein accumulation in traumatic brain injury. Neuromolecular Med 2003;4:59-72.

157. Newell KL, Boyer P, Gomez-Tortosa E, et al. Alpha-synuclein immunoreactivity is present in axonal swellings in neuroaxonal dystrophy and acute traumatic brain injury. J Neuropathol Exp Neurol 1999;12:1263-1268. 